\title{
TINDAK TUTUR DALAM PRAKTIK MENGAJAR MAHASISWA PENDIDIKAN PROFESI GURU (PPG) UNIVERSITAS PGRI ADI BUANA SURABAYA
}

\author{
Novia Vernawati \\ (Pendidikan Bahasa Indonesia, Fakultas Keguruan dan Imu Pendidikan, Universitas \\ PGRI Adi Buana Surabaya) \\ noviavernawati09@gmail.com \\ Agung Pramujiono \\ (Pendidikan Bahasa Indonesia, Fakultas Keguruan dan Imu Pendidikan, Universitas \\ PGRI Adi Buana Surabaya) \\ agungpramujiono.unipasby@gmail.com
}

\begin{abstract}
This research has a background in the function of language as a communication tool. Every human being has a communication tool used in everyday life. Humans use language to express ideas, thoughts, opinions, and interact with each other.The purpose of this study is to describe speech acts in teaching practices for students of Teacher Professional Education PGRI Adi Buana University Surabaya. The theory used in this study is the theory of speech acts from Searle. The method used in this research is descriptive qualitative. Data collection techniques using documents. The data analysis techniques used are data reduction, coding, and data presentation. The results of the study found there are directive speech acts and expressive speech acts. The directive speech acts consist of six types, namely the request directive speech act, the question directive speech act, the directive speech act of the directive, the prohibition directive speech, the directive act of giving permission and the non-directive advice directing. Whereas the expressive speech act function consists of expressive greetings of congratulations, expressive expressions of thanks, expressive expressions of criticism, expressive expressions of praise, expressive insinuations and expressive expressions of apology.
\end{abstract}

Keywords: speech acts, directive speech acts, expressive speech acts, function

\section{PENDAHULUAN}

Peran guru memang sangat penting dalam dunia pendidikan. Dengan demikian, guru sebagai seseorang yang berwenang untuk mengajar dan mendidik peserta didik harus memiliki kualifikasi dan kompetensi yang baik dan benar agar dapat merubah perilaku peserta didik menjadi lebih baik secara efektif dan efisien. Kompetensi guru tersebut berdasarkan Undang-Undang Nomor 14 Tahun 2005 tentang Guru dan
Dosen Bab IV Pasal 10 terdapat empat kompetensi yaitu kompetensi pedagogik, kepribadian, sosial, dan professional. Di zaman sekarang terdapat tuntutan keterampilan abad 21 yang harus dipahami oleh guru agar peserta didik mampu mempraktekan

pengetahuannya untuk memahami dan memberikan solusi pada tantangan di dunia nyata. Tindak tutur merupakan tindak yang dilakukan 
oleh penutur terhadap mitra tutur dengan tujuan dan maksud tertentu.

Berdasarkan penjelasan di atas, penulis tertarik melakukan penelitian ini dengan judul "Tindak Tutur dalam Praktik Mengajar Mahasiswa Pendidikan Profesi Guru (PPG) Universitas PGRI Adi Buana Surabaya". Alasan ketertarikan dalam pemilihan topik penelitian ini adalah sebagian besar tuturan-tuturan dalam proses pembelajaran terutama pada praktik mengajar mahasiswa Pendidikan Profesi Guru (PPG) Universitas PGRI Adi Buana Surabaya mengandung maksud dan tujuan tertentu. Tuturan-tuturan itu dapat diketahui melalui analisis tindak tutur yang disertai dengan konteks dari tuturan-tuturan tersebut. Tujuan dari penelitian ini adalah untuk mendeskripsikan tentang tindak tutur dalam praktik mengajar mahasiswa Pendidikan Profesi Guru (PPG) Universitas PGRI Adi Buana Surabaya. Penelitian ini diharapkan dapat bermanfaat bagi dunia kebahasaan dan pengajaran terkait dengan bidang wacana, serta dapat memperkaya pengetahuan dalam bidang pragmatik terutama tentang tindak tutur dalam proses komunikasi.

Keterampilan berbahasa tidak hanya berkaitan dengan aspek kebahasaan tetapi juga berkaitan dengan keterampilan pragmatik. Menurut (Yule, 2006: 3-4) pragmatik adalah studi tentang maksud, studi tentang makna kontekstual, studi tentang bagaimana agar lebih banyak yang disampaikan daripada yang dituturkan, dan studi tentang ungkapan dari jarak hubungan. Searle (dalam Rohmadi, 2004: 29) menegaskan bahwa tindak tutur adalah produk atau hasil dari suatu kalimat dalam kondisi tertentu yang dapat berwujud pernyataan, pertanyaan, perintah, atau yang lainnya. Tindak tutur adalah suatu tuturan yang digunakan untuk berinteraksi sesama manusia dengan maksud atau tujuan tertentu.

Di dalam tindak tutur, Searle (dalam Wijana, 1996: 17-19) mengemukakan bahwa secara pragmatis setidaknya ada tiga jenis tindakan yang dapat diwujudkan oleh seorang penutur, yakni tindak lokusi (locutionary act), tindak ilokusi (ilocutionary act), dan tindak perlokusi (perlocutionary act).

1) Tindak tutur lokusi merupakan tindak tutur untuk menyatakan sesuatu. Tuturan yang disampaikan sesuai dengan makna yang terdapat pada kalimat diujarkan.

2) Tindak ilokusi adalah tindak tutur yang diidentifikasikan dengan kalimat performatif yang eksplisit. Dengan demikian dapat dijelaskan bahwa tindak ilokusi sangat sukar diidentifikasi karena terlebih dahulu harus mempertimbangkan siapa penutur dan lawan tutur, kapan dan dimana tindak tutur itu terjadi, dan sebagainya.

3) Tindak tutur perlokusi adalah tindak tutur yang berkenaan dengan adanya ucapan orang lain sehubungan dengan sikap dan perilaku non-linguistik dari orang lain itu (Chaer dan Agustina, 2004: 53). Pada tindak tutur perlokusi, tuturan yang diucapkan penutur memiliki efek atau daya pengaruh kepada lawan tutur.

Menurut Yule (2006: 92-94) sistem klasifikasi umum mencantumkan lima jenis fungsi umum yang ditunjukkan oleh tindak tutur, yaitu: tindak tutur deklarasi, tindak tutur direktif, tindak tutur komisif, tindak tutur ekspresif, dan tindak tutur representatif. Tindak tutur ekspresif merupakan jenis 
tindak tutur yang menyatakan sesuatu yang dirasakan oleh penutur. Adapun beberapa jenis dan fungsi tuturan ekspresif yang terdapat dalam sebuah ujaran yang disampaikan oleh penutur kepada lawan tuturnya, yakni dapat berfungsi untuk mengucapkan selamat, terima kasih, mengkritik, permintaan maaf, menyalahkan, menyanjung atau memuji, dan menyindir. Tindak tutur direktif merupakan jenis tindak tutur yang dipakai oleh penutur untuk menyuruh orang lain melakukan sesuatu. Jenis tindak tutur ini menyatakan apa saja yang menjadi keinginan penutur. Dalam tindak tutur ini terdiri dari perintah, pemesanan, permohonan, dan pemberian saran.

\section{METODE PENELITIAN}

metode Pada penelitian ini digunakan Penelitian kualitatif deskriptif adalah penelitian yang menggunakan data deskriptif berupa kata-kata tertulis atau lisan dari objek yang alamiah. Tujuan yang dicapai dalam penelitian ini adalah paparan tindak tutur direktif dan ekspresif pada saat praktik mengajar mahasiswa Pendidikan Profesi Guru (PPG) Universitas PGRI Adi Buana. Data dalam penelitian ini berupa tuturan direktif dan ekspresif mahasiswa Pendidikan Profesi Guru (PPG) Universitas PGRI Adi Buana Surabaya. Sedangkan Sumber data yang digunakan dalam penelitian ini diperoleh dari dokumentasi berupa video praktik proses pembelajaran mahasiswa Pendidikan Profesi Guru (PPG) Universitas PGRI Adi Buana Surabaya. Teknik pengumpulan data dalam penelitian ini adalah menggunakan teknik dokumentasi, simak, catat dan simak bebas cakap. Menurut Sugiyono (2011: 240) dokumen merupakan catatan peristiwa yang sudah berlalu. Dokumen dapat berupa tulisan, gambar, atau karya-karya monumental dari seseorang. Teknik simak adalah teknik yang digunakan dalam penyediaan data dengan cara peneliti melakukan penyimakan penggunaan bahasa. Teknik catat digunakan sebagai teknik dalam pengumpulan data. Sedangkan teknik ini digunakan penulis karena penelitian yang dilakukan oleh penulis tanpa terlibat dalam dialog, konversasi, atau imbal wicara. Analisis data merupakan upaya yang dilakukan untuk mengklasifikasi, pengelompokan data. Adapun tahapan dan langkah-langkah analisis data yang dilakukan dalam penelitian ini yaitu (a) reduksi data, (b) pengkodean, dan (3) penyajian data.

\section{HASIL PENELITIAN DAN PEMBAHASAN}

Dari data-data yang diperoleh dan dibahas merupakan tindak tutur direktif dan ekspresif yang digunakan pada saat interaksi proses belajar mengajar dalam praktik mengajar mahasiswa Pendidikan Profesi Guru (PPG) Universitas PGRI Adi Buana Surabaya.

\section{Bentuk Tindak Tutur Direktif}

a. Tuturan direktif permintaan (Requstives)

Tindak permintaan (requstives) menunjukkan dalam mengucapkan suatu tuturan, penutur memohon kepada mitra tutur untuk melakukan sesuatu.

(1) Guru :"baik, pertama-tama puji dan syukur kita panjatkan atas kehadirat sang pencipta karena pada kesempatan ini kita bisa kembali bertatap muka di tempat ini. Untuk melanjutkan pembelajaran kita pada mata 
pelajaran Pendidikan Pancasila dan Kewarganegaraan. Nah untuk mengawali pembelajaran kita pada pagi hari ini, untuk mewujudkan rasa syukur kita terhadap sang pencipta terlebih dahulu marilah kita bersam-sama memanjatkan doa kepada sang pencipta yang pada kesempatan ini saya persilakan kepada nak Ilham untuk memimpin rekanrekannya. Silakan" V1-1.4

Konteks (1) : untuk mengawali pembelajaran guru meminta peserta didik agar berdoa terlebih dahulu. Salah satu peserta didik memimpin teman-temannya berdoa.

Data (1) dapat diperhatikan bahwa tuturan yang disampaikan oleh guru termasuk dalam tindak tutur direktif permintaan. Guru meminta peserta didik agar berdoa terlebih dahulu sebelum proses pembelajaran berlangsung yang ditandai dengan kalimat "Nah untuk mengawali pembelajaran kita pada pagi hari ini, untuk mewujudkan rasa syukur kita terhadap sang pencipta terlebih dahulu marilah kita bersama-sama memanjatkan doa kepada sang pencipta yang pada kesempatan ini saya persilakan kepada nak Ilham untuk memimpin rekan-rekannya."

b. Tindak tutur direktif pertanyaan (Questions)

Tindak tutur direktif (questions) menunjukkan bahwa dalam mengucapkan suatu tuturan, penutur menanyakan pada mitra tutur tentang kebenaran suatu proposisi. Guru:"ya untuk isi laporan teks hasil observasi. Kemarin terdiri dari berapa bagian?" V3-1.162
Konteks (2) : guru memberikan pertanyaan kepada peserta didik mengenai jumlah bagian dari isi laporan teks hasil observasi.

Data (2) dapat diperhatikan tuturan yang disampaikan oleh guru termasuk dalam tindak tutur direktif pertanyaan. Guru bertanya kepada peserta didik mengenai jumlah dari isi laporan teks hasil observasi dengan tuturan "ya untuk isi laporan teks hasil observasi. Kemarin terdiri dari berapa bagian?"

c. Tindak tutur perintah

Tindakan perintah (requirements) menunjukkan bahwa ketika mengucapkan suatu tuturan, penutur harus menghendaki mitra tutur untuk melakukan perbuatan.

(3) Guru :"sudah ya silakan. Setiap kelompok sekarang memilih ketuanya" V3-1.154

Konteks (3) : guru memberikan perintah kepada peserta didik bahwa setiap kelompok harus menentukan ketuanya.

Data (3) dapat diperhatikan tuturan guru termasuk ke dalam tindak tutur direktif perintah. Guru memberikan perintah kepada peserta didik untuk menentukan ketua kelompok dengan tuturan "Setiap kelompok sekarang memilih ketuanya."

d. Tindak tutur larangan (Prohibitive)

Dalam tindak tutur larangan penutur mengekspresikan maksud agar mitra tutur tidak melakukan tindakan karena ujaran penutur.

(4) Guru :"waktunya 5menit" V12.46 
Konteks (4) : guru memberikan batasan kepada peserta didik agar saat mengerjakan tugas waktunya tidak lebih dari 5 menit.

Data (4) dapat diperhatikan tuturan guru termasuk ke dalam tindak tutur direktif larangan karena termasuk membatasi peserta didik. Guru memberikan waktu hanya 5 menit untuk mengerjakan tugas dan tidak boleh lebih dengan tuturan "waktunya 5 menit."

e. Tindak tutur direktif pemberian izin

Tindakan permissives merupakan suatu tindakan bahwa ketika mengucapkan suatu tuturan menghendaki mitra tutur untuk melakukan perbuatan (tindakan).

(5) Guru :"iya. Ya jadi 3 kelompok masing-masing anggota kelompok tuh ada 3 siswa silakan berhitung" V3-1.153

Konteks (5) guru memperbolehkan peserta didik untuk memulai berhitung guna menentukan anggota kelompoknya.

Data (5) dapat diperhatikan tuturan guru termasuk ke dalam tindak tutur direktif pemberian izin. Guru memperbolehkan peserta didik untuk memulai berhitung agar anggota kelompoknya dapat dibagi rata dengan tuturan "Ya jadi 3 kelompok masing-masing anggota kelompok tuh ada 3 siswa silakan berhitung"

f. Tindak tutur direktif nasihat (Advisories)

Tindakan advisories merupakan tindakan yang ketika mengucapkan suatu ekspresi penutur menasihati mitra tutur untuk melakukan tindakan.

(6) Guru :“ Nah jadi anak-anak ku sekalian apapun yang kita laksanakan, apapun yang akan kita kerjakan selalu diawali dengan doa. Kenapa? Karena itu adalah bentuk wujud rasa syukur kita terhadap tuhan yang maha esa."

V1-1.5

Konteks (6): guru memberikan nasihat kepada peserta didik agar peserta didik selalu berdoa terlebih dahulu sebelum mengerjakan atau melakukan sesuatu.

Data (6) dapat diperhatikan tuturan guru termasuk ke dalam tindak tutur direktif nasihat. Guru memberikan nasihat kepada peserta didik agar peserta didik selalu memulai dengan doa sebelum melakukan suatu pekerjaan dengan tuturan "Nah jadi anak-anak ku sekalian apapun yang kita laksanakan, apapun yang akan kita kerjakan selalu diawali dengan doa."

\section{Bentuk Tindak Tutur Ekspresif}

a. Tuturan ekspresif ucapan selamat Tuturan ekspresif ucapan selamat merupakan tindak tutur yang bertujuan untuk mengucapkan selamat meliputi pujian, penutur memberikan sambutan istimewa kepada mitra tutur, sambutan atau salam penanda waktu sehingga mitra tuturnya mengucapkan selamat kepada penutur sebagai ekspresi kebahagiaan.

(7) Guru:"selamat pagi anak-anak" V3-1.137 
Konteks (7) : Guru membuka awalan kegiatan pembelajaran dengan ucapan selamat pagi untuk peserta didik.

Data (7) dapat diperhatikan bahwa tuturan yang disampaikan oleh guru termasuk dalam tindak tutur ekspresif ucapan selamat. Dalam tuturan tersebut guru menyapa peserta didik terlebih dahulu dengan ucapan selamat pagi pada tuturan "selamat pagi anak-anak"

\section{b. Tuturan ekspresif ucapan terima kasih}

Tuturan ekspresif ucapan terima kasih merupakan tindak tutur yang biasanya terjadi karena beberapa faktor, yaitu mitra tutur bersedia melakukan apa yang diminta oleh penutur, hal tersebut dikarenakan tuturan 'memuji' yang dituturkan oleh penutur kepada mitra tutur, atau karena kebaikan hati penutur yang telah memberikan sesuatu kepada mitra tutur.

(8) Guru :"terima kasih, ibu ambil hitamnya" V23.127

Konteks (8) : Guru mengucapkan terima kasih kepada salah satu peserta didik karena telah memberikan spidol yang telah guru pinjam.

Data (8) dapat diperhatikan bahwa tuturan yang disampaikan oleh guru tersebut termasuk dalam tindak tutur ekspresif bentuk terima kasih. Guru berterima kasih kepada salah satu peserta didik yang telah memberikan spidol berwarna hitam karena spido yang digunakan habis isinya dengan tuturan "terima kasih, ibu ambil hitamnya"

c. Tuturan ekspresif mengkritik
Tuturan ekspresif mengkritik merupakan tindak tutur yang terjadi karena penutur merasa tidak sependapat dengan apa yang dilakukan oleh mitra tutur.

(9) Guru :"Anifa, iya angkat tangan dulu ya yang pertama baik ayo" V2-2.86

Konteks (9) : guru memberikan kritikan kepada salah satu peserta didik untuk angkat tangan terlebih dahulu sebelum menjawab pertanyaan.

Data (9) dapat diperhatikan bahwa tuturan yang disampaikan oleh guru tersebut termasuk dalam tindak tutur ekspresif mengkritik. Tuturan guru pada muridnya bermaksud untuk mengungkapkan kritikan kepada salah satu peserta didik dan memberi arahan agar angkat tangan terlebih dahulu sebelum menjawab pertanyaan dengan tuturan "Anifa, iya angkat tangan dulu ya yang pertama baik ayo"

\section{d. Tuturan ekspresif memuji}

Tuturan ekspresif memuji merupakan tindak tutur yang terjadi karena beberapa faktor, yaitu kondisi dari mitra tutur yang sesuai dengan kenyataan yang ada, karena penutur ingin melegakan hati mitra tutur, penutur ingin merayu mitra tutur, penutur ingin menyenangkan hati mitra tutur, dan karena perbuatan terpuji yang dilakukan oleh mitra tutur.

(10) Guru :"iya jadi bener betul sekali ya sudah ingatannya begitu kuat jadi saya seneng mengajar di kelas ini ya" V3-1.166 
Konteks (10) : guru memuji peserta didik karena masih ingat dengan materi yang telah dipelajari oleh peserta didik sebelumnya.

Data (10) dapat diperhatikan bahwa tuturan yang disampaikan oleh guru tersebut termasuk dalam tindak tutur ekspresif memuji. Dalam tuturan tersebut guru memuji peserta didiknya karena masih ingat dengan materi yang telah dipelajari sebelumnya pada tuturan "iya jadi bener betul sekali ya sudah ingatannya begitu kuat jadi saya seneng mengajar di kelas ini ya"

\section{e. Tuturan ekspresif menyindir}

Tuturan ekspresif menyindir merupakan tuturan yang terjadi karena beberapa faktor, yaitu penutur tidak suka dengan apa yang dilakukan oleh mitra tutur, penutur menyampaikan alasan-alasan yang tidak masuk akal kepada mitra tutur, atau tuturan pernyataan penutur terhadap mitra tutur.

(11) Guru :"iya, sekali lagi untuk laki-laki boleh nak Bambang diperjelas kembali” V1-1.11

Konteks (11) : Guru memberikan sindiran kepada peserta didik laki-laki untuk memperjelas kembali tujuan pembelajaran yang telah ditampilkan.

Data (11) dapat diperhatikan bahwa tuturan yang disampaikan oleh guru tersebut termasuk dalam tindak tutur ekspresif menyindir. Dalam tuturan tersebut guru menyindir peserta didik laki-laki untuk memperjelas kembali tujuan pembelajaran yang telah dibacakan oleh salah satu peserta didik. dengan tuturan ":"iya, sekali lagi untuk laki-laki boleh nak Bambang diperjelas kembali"

\section{f. Tuturan ekspresif permintaan maaf} Tuturan ekspresif permintaan maaf merupakan tindak tutur biasanya dilakukan atas kesalahan yang telah diperbuat sebagai bentuk rasa sopan ketika bertanya, atau permintaan ijin melakukan sesuatu.

(12) Guru :"nah terima kasih nak Lestari. Lebih kekurangannya mohon dimaafkan." V1-2.49

Konteks (12) : Guru meminta maaf kepada peserta didik sebelum mengakhiri pembelajaran.

Data (12) dapat diperhatikan bahwa tuturan yang disampaikan oleh guru tersebut termasuk dalam tindak tutur ekspresif permintaan maaf "nah terima kasih nak Lestari."

Pada hasil analisis dapat dijelaskan bahwa penggunaan tuturan dalam praktik mengajar mahasiswa PPG terdapat beberapa fungsi tindak tutur. Penelitian ini sangat berbeda dengan penelitian sebelumnya karena dalam penelitian ini menggunakan dua tindak tutur untuk membandingkan kesamaan dan perbedaan dari segi tuturan yang telah diujarkan oleh guru. mohon dimaafkan.

\section{SIMPULAN}

Berdasarkan hasil penelitian disimpulkan bahwa bentuk-bentuk tindak tutur direktif dan ekspresif guru dalam proses praktik mengajar mahasiswa Pendidikan Profesi Guru (PPG) Universitas PGRI Adi Buana Surabaya terdapat dua belas jenis. Jenis tindak tutur tersebut terdiri dari 
enam fungsi tindak tutur direktif dan enam fungsi tindak tutur ekspresif.

Fungsi tindak tutur direktif antara lain tindak tutur direktif permintaan, tindak tutur direktif pertanyaan, tindak tutur direktif perintah, tidak tutur direktif larangan, tindak tutur direktif pemberian izin dan tidak tutur direktif nasihat. Sedangkan untuk fungsi tindak tutur ekspresif terdiri dari tuturan ekspresif ucapan selamat, tuturan ekspresif ucapan terima kasih, tuturan ekspresif mengkritik, ucapan eksresif memuji, ucapan ekspresif menyindir dan ucapan ekspresif permintaan maaf.

Dari hasil penelitian penulis memeroleh 3 dokumen video yang dijadikan sebagai data analisis. Dalam penelitian ini terdapat 35 penggunaan jenis tindak tutur direktif dan ekspresif.

DAFTAR PUSTAKA

Chaer, Abdul dan Agustina, Leoni. 2004.Sosiolinguistik

Perkenalan Awal. Jakarta: Rineka Cipta.

Ibrahim, Abd.Syukur. 1993. Kajian

Tindak Tutur. Surabaya: Usaha Nasional.

Mahsun. 2005. Metode Penelitian Bahasa. Jakarta: PT Raja Grafindo Persadaa.

Moleong, Lexy J. 2011. Metodologi Penelitian Kualitatif Edisi Revisi. Bandung: PT Remaja Rosdakarya.

Rohmadi, Muhammad. 2004. Pragmatik: Teori dan Analisis. Yogyakarta: Lingkar Media.

Sugiyono. 2011. Metode Penelitian Kuantitatif, Kualitatif dan $R \& D$. Bandung: Alfabeta.

Tarigan, Henry Guntur. 2009.

$$
\text { Pengajaran Pragmatik. }
$$
Bandung: Angkasa Bandung.
Wijana, I Dewa Putu. 1996.

Dasar-Dasar Pragmatik. Yogyakarta: Andi Offset.

Yule, George. 2006. Pragmatik. Yogyakarta: Pustaka Pelajar Offsed. 